\title{
Editorial: Vegetation Effects on Soil Organic Matter in Forested Ecosystems
}

\author{
Jérôme Laganière ${ }^{1 *}$, Laurent Augusto ${ }^{2}$, Jeff Allen Hatten ${ }^{3}$ and Sandra Spielvogel ${ }^{4}$ \\ ${ }^{1}$ Laurentian Forestry Centre, Natural Resources Canada, Canadian Forest Service, Quebec, QC, Canada, ${ }^{2}$ INRA Centre \\ Bordeaux-Aquitaine, Bordeaux, France, ${ }^{3}$ Department of Forest Engineering, Resources and Management, College of \\ Forestry, Peavy Forest Science Center, Oregon State University, Corvallis, OR, United States, ${ }^{4}$ Department of Soil Science, \\ Institute for Plant Nutrition and Soil Science, Christian-Albrechts-University of Kiel, Kiel, Germany
}

Keywords: soil organic matter, forest vegetation, biogeochemical cycles, carbon stabilization, soil biota, soil respiration

\section{Editorial on the Research Topic}

\section{Vegetation Effects on Soil Organic Matter in Forested Ecosystems}

\section{OPEN ACCESS}

Edited and reviewed by: Frank Hagedorn, Swiss Federal Institute for Forest, Snow and Landscape Research (WSL), Switzerland

*Correspondence: Jérôme Laganière jerome.laganiere@canada.ca

Specialty section: This article was submitted to Forest Soils,

a section of the journal Frontiers in Forests and Global

Change

Received: 03 December 2021 Accepted: 13 December 2021 Published: 06 January 2022

Citation: Laganière J, Augusto L, Hatten JA and Spielvogel S (2022) Editorial: Vegetation Effects on Soil Organic Matter in Forested Ecosystems. Front. For. Glob. Change 4:828701. doi: 10.3389/ffgc.2021.828701
Soil organic matter (SOM) plays a crucial role in forest ecosystems including nutrient provision, carbon sequestration, water regulation, soil structuring, and biodiversity promotion, thus placing SOM as an indicator of soil health. Vegetation is the main source of SOM in soils through aboveand belowground inputs of organic matter. Vegetation also substantially influences various soil properties such as temperature, moisture, $\mathrm{pH}$, composition and activity of the soil biota (Binkley and Giardina, 1998; Mueller et al., 2015; Schelfhout et al., 2017). Hence, a shift in vegetation composition through natural succession, forest management and/or global changes may alter SOM dynamics and related ecosystem services. Although the importance of plants in driving SOM formation and carbon cycling is now well-established, predicting SOM from vegetation composition in a variety of ecosystems is still challenging due to poor understanding of mechanisms and of potential interactions with biophysical attributes modulating vegetation-SOM relationships (Augusto et al., 2015; Mayer et al., 2020).

This Research Topic brought together research conducted in various ecosystems and climates, from the boreal forest of Canada to the Mediterranean region and wet tropical forest of Costa Rica. The contributions received were also very broad in term of spatial scale (from stand to landscape), SOM roles examined (e.g., carbon storage and stability, tree nutrition, soil respiration) and approaches used (from laboratory incubations to long-term field monitoring and meta-analysis).

In a 40 years old common garden experiment with five forest types in Argentina, Morazzo et al. observed significant differences in soil chemical and physical attributes, including SOM content, as well as in the morphology of soil profiles, in such as way that two forest types generated a change in the taxonomic order of the soil over time. In Italian mountain forests, Panico et al. found that together with site exposure and altitude, vegetation cover is a good predictor of soil characteristics including soil organic carbon. Tree species also have major effects on soils through their roots. In the tropical forest of Costa Rica, Russell et al. showed that litter inputs of fine roots and their biochemistry, especially the abundance of syringyl phenols, explain differences in organic carbon stocks among species. At a larger scale, Jandl et al. used data from the Austrian Forest Soil Survey to estimate current and projected soil carbon stocks at the country's scale under different forest managements and climate change scenarios. The concept letter by Desie et al. shows how threshold behavior in soil $\mathrm{pH}$ mediates tree species effects on carbon cycling and highlights that this parameter should be considered when managing forest composition to promote carbon sequestration. 
The contrasting influence of broadleaves on soils relative to conifers has been highlighted in past research (Prescott et al., 2000; Vesterdal et al., 2008; Augusto et al., 2015). Specifically, research on trembling aspen has shown that the abundance of this broadleaf species in North American forests can positively affect stand productivity, biodiversity, nutrient cycling and water retention (Laganière et al., 2017). We further learn from Boca et al. that soils developed under aspen retain more dissolved organic carbon than soils developed under conifers, which has implications for carbon stability via the formation of organomineral associations. The direct impact of a vegetation shift on substrate utilization efficiency and incorporation into microbial biomass is investigated in the Lloret and Quideau paper using ${ }^{13} \mathrm{C}$ labeled substrates. Their lab experiment indicates that a shift from spruce to aspen could be accompanied by litter C losses through microbial respiration but that incorporation into microbial biomass and eventually into the more persistent soil carbon pool may not be affected. In Nickels and Prescott, the stability of soil organic matter produced by aspen-dominated, conifer or grass vegetation in post-mining reclaimed ecosystems is investigated. The authors found that the type of vegetation established has important implications for SOC persistence in these systems.

Managing forests in mixed-species stands could also be a way of enhancing productivity and carbon sequestration as well as promoting resilient soil functions (Binkley et al., 2003; Hooper et al., 2005; Laganière et al., 2015). A meta-analysis by Rehschuh et al. showed that diversification of European beech forests, and especially beech-conifer admixtures, may

\section{REFERENCES}

Augusto, L., De Schrijver, A., Vesterdal, L., Smolander, A., Prescott, C., and Ranger, J. (2015). Influences of evergreen gymnosperm and deciduous angiosperm tree species on the functioning of temperate and boreal forests. Biol. Rev. Camb. Philos. Soc. 90, 444-466. doi: 10.1111/brv.12119

Binkley, D., and Giardina, C. (1998). Why do tree species affect soils? The warp and woof of tree-soil interactions. Biogeochemistry 42, 89-106. doi: 10.1023/A:1005948126251

Binkley, D., Senock, R., Bird, S., and Cole, T. G. (2003). Twenty years of stand development in pure and mixed stands of Eucalyptus saligna and nitrogen-fixing Facaltaria moluccana. For. Ecol. Manag. 182, 93-102. doi: 10.1016/S0378-1127(03)00028-8

Hooper, D. U., Chapin III, F. S., Ewel, J. J., Hector, A., Inchausti, P., Lavorel, S. et al. (2005). Effects of biodiversity on ecosystem functioning: a consensus of current knowledge. Ecol. Monogr. 75, 3-35. doi: 10.1890/04-0922

Laganière, J., Boča, A., Van Miegroet, H., and Paré, D. (2017). A tree species effect on soil that is consistent across the species' range: The case of aspen and soil carbon in North America. Forests. 8, 113. doi: 10.3390/f8040113

Laganière, J., Cavard, X., Brassard, B. W., Paré D., Bergeron, Y., and Chen, H. Y. H. (2015). The influence of boreal tree species mixtures on ecosystem carbon storage and fluxes. For. Ecol. Manag. 354, 119-129. doi: 10.1016/j.foreco.2015.06.029

Mayer, M., Prescott, C. E., Abaker, W. E. A., Augusto, L., Cécillon, L., Ferreira, G. W. D. et al. (2020). Tamm Review: Influence of forest management activities on soil organic carbon stocks: A knowledge synthesis. For. Ecol. Manag. 466, 118127. doi: 10.1016/j.foreco.2020.118127

Mueller, K. E., Hobbie, S. E., Chorover, J., Reich, P. B., Eisenhauer, N., Castellano, M. J. et al. (2015). Effects of litter traits, soil biota, and soil chemistry on soil carbon stocks at a common garden with 14 tree species. Biogeochemistry 123, 313-327. doi: 10.1007/s10533-015-0083-6 benefit soil carbon and nitrogen storage and serve as an adaptation measure for drought-sensitive beech forests under climate change. Another study looking at species mixtures, the Bélanger et al. study, illustrates how the presence of balsam fir and American beech in sugar maple dominatedforests affect soil respiration in opposite directions, through their different ecophysiological activity, light interception and litter quality.

Collectively, results from these studies highlight that vegetation influences SOM accumulation, persistence and release through various mechanisms. Continuous research effort is needed to gain more insight into the role of vegetation on SOM cycling in the ecosystems of the world. Such knowledge is crucial to increase our ability to manage vegetation composition to maintain and enhance SOM, and to promote more resilient ecosystems services in a changing world.

\section{AUTHOR CONTRIBUTIONS}

JL prepared the draft. LA, JH, and SS revised the draft. All authors approved the final submission.

\section{ACKNOWLEDGMENTS}

This Research Topic would not have been possible without the contribution of Antra Boca of Latvia University of Life Sciences and Technologies. We are grateful to all authors and reviewers for their contributions to this topic as well as the support of the editorial office.

Prescott, C. E., Zabek, L. M., Staley, C. L., and Kabzems, R. (2000). Decomposition of broadleaf and needle litter in forests of British Columbia: influences of litter type, forest type, and litter mixtures. Can. J. For. Res. 30, 1742-1750. doi: 10.1139/x00-097

Schelfhout, S., Mertens, J., Verheyen, K., Vesterdal, L., Baeten, L., Muys, B. et al. (2017). Tree Species Identity Shapes Earthworm Communities. Forests 8, 85. doi: 10.3390/f80 30085

Vesterdal, L., Schmidt, I. K., Callesen, I., Nilsson, L. O., and Gundersen, P. (2008). Carbon and nitrogen in forest floor and mineral soil under six common European tree species. For. Ecol. Manag. 255, 35-48. doi: 10.1016/j.foreco.2007. 08.015

Conflict of Interest: The authors declare that the research was conducted in the absence of any commercial or financial relationships that could be construed as a potential conflict of interest.

Publisher's Note: All claims expressed in this article are solely those of the authors and do not necessarily represent those of their affiliated organizations, or those of the publisher, the editors and the reviewers. Any product that may be evaluated in this article, or claim that may be made by its manufacturer, is not guaranteed or endorsed by the publisher.

Copyright (C) 2022 Laganière, Augusto, Hatten and Spielvogel. This is an open-access article distributed under the terms of the Creative Commons Attribution License (CC $B Y)$. The use, distribution or reproduction in other forums is permitted, provided the original author(s) and the copyright owner(s) are credited and that the original publication in this journal is cited, in accordance with accepted academic practice. No use, distribution or reproduction is permitted which does not comply with these terms. 